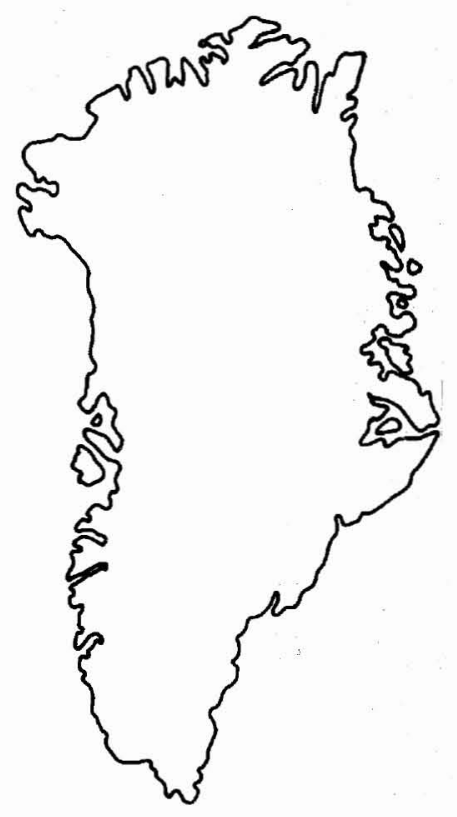

\title{
Organic geochemistry of the Lower Jurassic Sortehat Formation, Jameson Land, East Greenland
}

\author{
Helle Krabbe, Flemming G. Christiansen, \\ Gregers Dam, Stefan Piasecki and Lars Stemmerik
}

\begin{abstract}
Biomarker analyses of Lower Jurassic shales from the Sortehat Formation, Jameson Land, central East Greenland carried out in combination with palynological studies demonstrate deposition in a fresh to brackish water environment, which became increasingly saline towards the top. The formation is regionally immature to early mature with respect to hydrocarbon generation, and the lowermost 2-20 m have a fair generation potential. Biomarker analysis of the brackish water part shows dominance of $\mathrm{C}_{16}-\mathrm{C}_{21} n$-alkanes, high pristane/phytane ratios, high hopane/sterane ratios, high relative amounts of $\mathrm{C}_{29}-\mathrm{C}_{31}$ hopanes and $\mathrm{C}_{27} 17 \alpha$-trisnorhopane. Steranes are dominated by $\mathrm{C}_{29}$ isomers. The organic matter is composed of bacteria, algae and land plants interpreted from biomarker distributions. The combined data set suggests that deposition took place during an overall rise in relative sea level.
\end{abstract}

H. K., Geological Institute, University of Copenhagen, $\emptyset_{\text {ster Voldgade } 10, D K-1350}$ Copenhagen K, Denmark. Present address: Maersk Oil and Gas AS, Esplanaden 50, $D K-1263$ Copenhagen K, Denmark.

F. G. C., G. D., S. P. \& L. S., Geological Survey of Greenland, Øster Voldgade 10 , DK-1350 Copenhagen K, Denmark.

The Upper Palaeozoic and Mesozoic sedimentary basins in East Greenland contain a number of organic-rich units which, depending on adequate burial history, may have a potential for generation of liquid hydrocarbons or gas. So far 10 organic-rich units have been identified (see review by Christiansen et al., 1992). The majority of these units are well exposed, and detailed studies of their sedimentology, stratigraphy and organic geochemistry provide important data on source rock potential and oil to source rock correlation not only in East Greenland but also for other sedimentary basins in the North Atlantic borderlands especially the mid-Norwegian Continental Shelf.

Most of the organic-rich units have been studied in considerable detail using a multidisciplinary approach, combining sedimentology, palynology and organic geochemistry (see review by Christiansen et al., 1992).

One of the least studied units is the Lower Jurassic Sortehat Formation in Jameson Land (Fig. 1). A preliminary assessment suggested a limited source potential (Piasecki, 1987; Christiansen et al., 1992). The unit is, however, important in a basin analysis study as it seems to reflect a change in depositional environment from brackish to fully marine conditions.
In the present paper, all available sedimentological, stratigraphic and organic geochemical results are summarised and the depositional environment is discussed with main emphasis on distribution of biomarkers (steranes and hopanes). Previous conclusions on the limited source potential are confirmed, but important data on the geochemical evolution of the depositional environment are provided.

\section{Geological setting}

The Jameson Land basin is the southernmost of a series of Late Palaeozoic - Mesozoic basins which are exposed onshore East Greenland. Basin formation started during the Late Palaeozoic and during Mesozoic times the Jameson Land basin subsided mainly because of thermal cooling.

The basin was bounded to the west by a major fault zone and to the east by a NNE-SSW elongated landmass covering the present-day Liverpool Land. To the north the basin was bounded by a NW-SE cross-fault in Kong Oscar Fjord (Surlyk, 1977a,b, 1990b; Surlyk et al., 1981). The southern boundary is unknown but the basin 


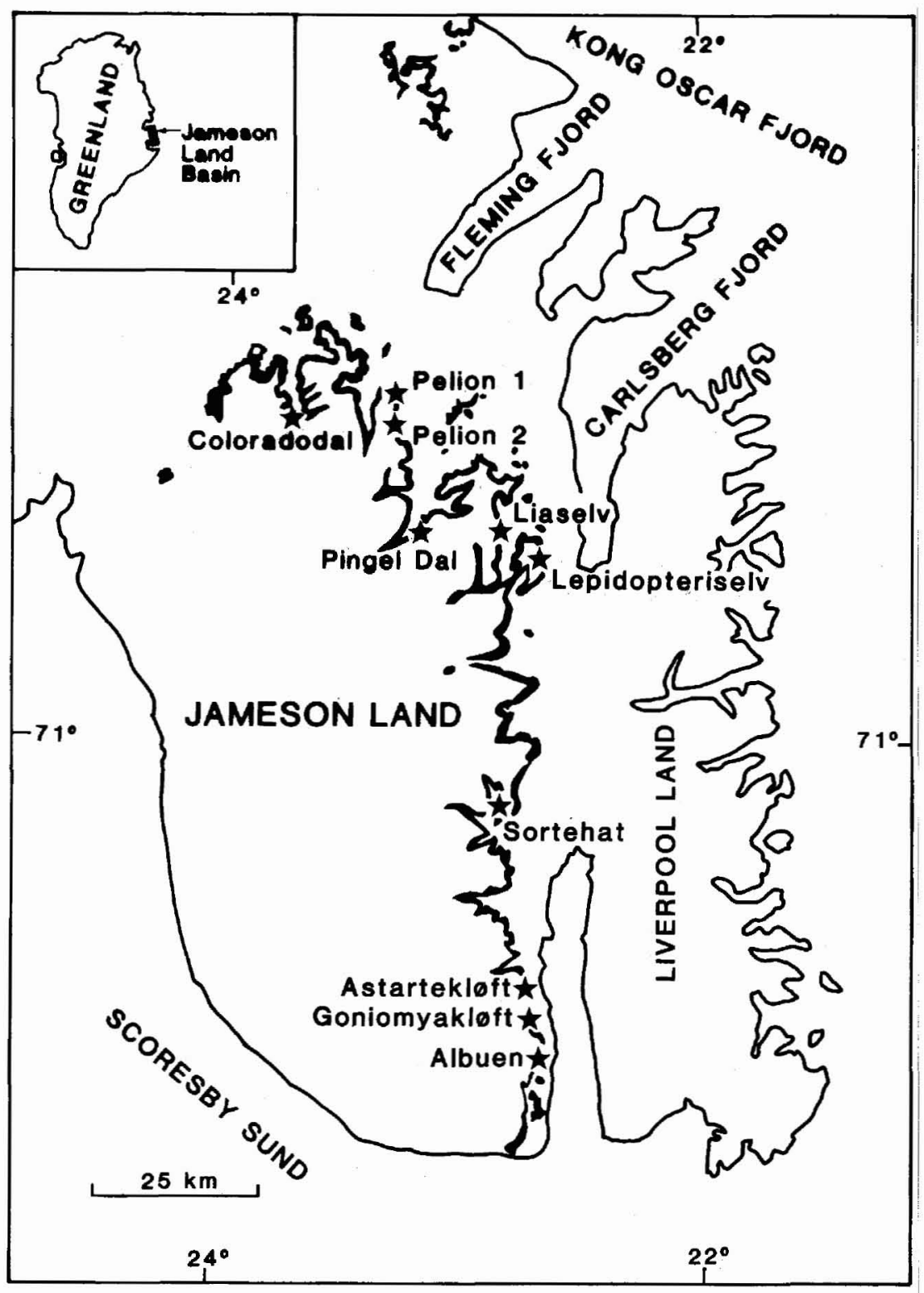

Fig. 1. Map showing outcrop of the Sortehat Formation (in black) and sections sampled (asterisks).

probably extended farther south than Scoresby Sund (Fig. 1).

The (?)uppermost Toarcian - (?)Bajocian Sortehat Formation consists of homogeneous dark grey to black shales. The Sortehat Formation was originally defined as the basal member of the Middle Jurassic Vardekløft Formation (Surlyk et al., 1973), but was recently established as a separate formation (Surlyk, 1990a; Fig. 2).

The lower boundary is sharp and marked by a marine erosion surface separating the dune field deposits of the late Toarcian/?Aalenian Ostreaelv Member, Neill Klinter
Formation from the restricted shelf deposits of the Sortehat Formation (Surlyk, 1990a, b, 1991; Dam, 1991). A thin pebble conglomerate is frequently present at the boundary. The Sortehat Formation is overlain by the upper Bajocian - middle Callovian Vardekløft Formation with a sharp, slightly unconformable contact (Surlyk, 1990a, b, 1991).

The Sortehat Formation shales consist of silty mudstone with very fine and fine-grained micaceous sandstone streaks. The sandstone streaks show pinch and swell structures, incipient lenses and parallel lamination 
Fig. 2. Stratigraphy of the Sortehat Formation and associated units of the Jurassic succession in Jameson Land.

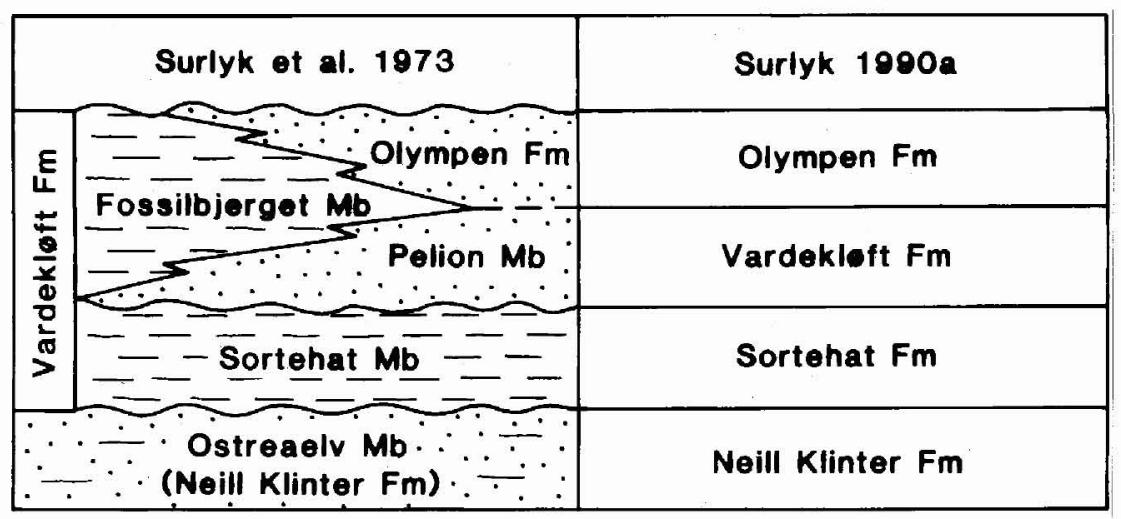

grading into wave ripple cross-lamination. The streaked mudstones locally contain highly disintegrated plant debris, early diagenetic phosphatic concretions and calcareous concretionary layers. Fossils include bivalves, mainly oyster fragments, and belemnites which frequently occur in the top of the formation (Surlyk et al., 1973). Locally, at Albuen, a large number of brachiopods occur in the basal part of the formation. The mudstones form one or two coarsening-upward successions and are commonly burrowed by Curvolithos multiplex and Planolites beverlyensis (Dam, 1991).

The streaked mudstones of the Sortehat Formation were deposited in a relatively deep embayment with restricted wave activity. Basin subsidence was mainly governed by thermal contraction and it has been suggested that the dominant control on deposition was sea-level changes superimposed on a steady tectonic subsidence in a period of relatively constant sediment input (Surlyk, 1990a, b, 1991; Dam, 1991).

\section{Age}

The age of the Sortehat Formation has never been precisely determined despite the abundant marine fauna, which, however, does not include ammonites (Surlyk et al., 1973). The underlying Ostreaelv Member contains belemnites of the Dimortieria levesquei Zone, suggesting a late Toarcian age for this member (Doyle, 1991). The Cranocephaloides borealis Zone of latest Bajocian age is present in the basal strata of the overlying Pelion Member. This leaves a possible age interval for the Sortehat Formation of late Toarcian, Aalenian to Bajocian (Surlyk et al., 1973).

A palynological study of the Sortehat Formation has recently been initiated. The preliminary results from this study suggest an Aalenian age of the formation (E. Koppelhus, personal communication, 1994).

Basin-wide hiatal omission surfaces are reported from the base and the top of the Sortehat Formation (Surlyk, 1990a, b, 1991; Dam, 1991). The composite biostratigraphic dating of the formation indicates deposition from late Toarcian to Bajocian, and it is suggested that no significant hiati are present in connection with the unconformities.

\section{Analytical methods}

Most of the analyses for screening purposes were carried out by the source rock laboratory at the Geological Survey of Denmark ( $n=96$ ) (see description of methods by Bojesen-Kofoed, 1989 and Christiansen et al., 1989). Total sulphur was analysed in a LECO furnace by Haldor Topsøe A/S, Copenhagen $(n=55)$.

Duplicate screening analyses $(n=15)$ and all of the extraction, gas chromatography (GC) and gas chromatography-mass spectrometry (GC-MS) $(n=15)$ were carried out at Norsk Hydro Research Center in Bergen.

Separation of the deasphalted extract was performed in $n$-pentane solution in a Bond-Elut system by passing the extract through a cyano (CN) filter, capturing the NSO compounds. The combined saturate and aromatic fraction was collected in a tube below.

Aliquots of the combined saturate and aromate fraction were analysed by GC and GC-MS analyses. A HP5890 gas chromatograph fitted with a non-polar silica column was used for separation. The mass spectrometer was a VG 70E model operated in both selective metastable ion monitoring (SMIM) mode and voltage selected ion recording (VSIR) mode. Both methods are described in Steen (1986).

The palynological preparation followed the standard procedures of hydrochloric and hydroflouric acid treatment and oxidising with fuming nitric acid followed by washing on a $20 \mu$ mesh-size filter cloth. Seventy-three samples from eight localities were scanned for microfossils, type of organic matter and sporomorph colours. 
Fig. 3. Simplified geochemical logs of the Gonyomyakløft, Sortehat, Lepidopteriselv, Liaselv, Pelion 1 and 2, Coloradodal and Pingeldal sections sampled with altitude, lithostratigraphy, TOC, hydrogen index (HI), total sulphur (TS) and $T_{\max }$ from RockEval pyrolysis.

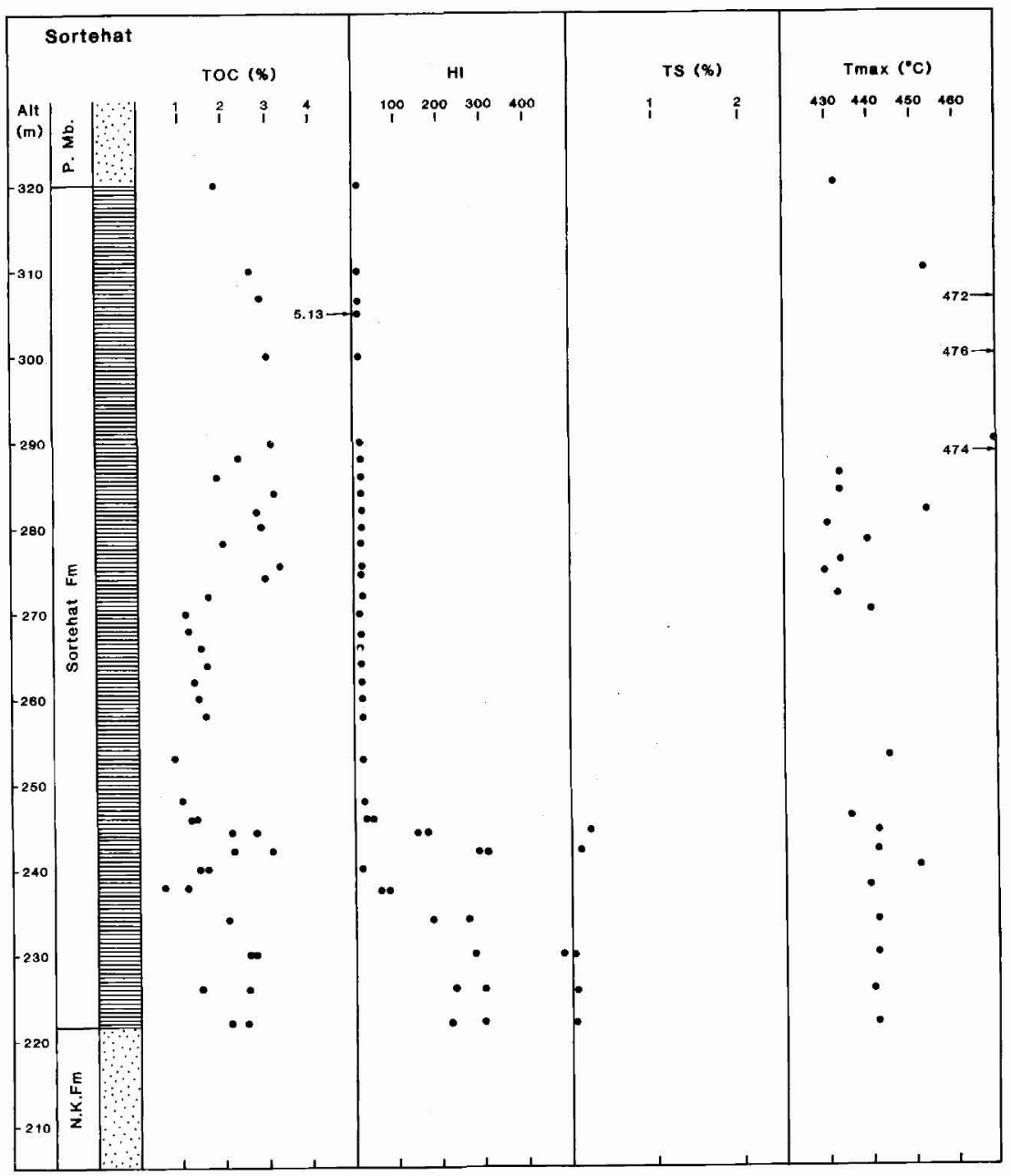

\section{Screening data}

\section{Organic Matter}

The shales of the Sortehat Formation show a relatively constant, but low, amount of organic matter, whereas the composition shows a considerable variation from base to top (Fig. 3).

The TOC content varies between 0.5 and $3.5 \%$ with a mode between 1 and $1.5 \%$, and an average of $1.47 \% \pm 0.65$ (Fig. 3). The highest values are recorded from the lowest $10 \mathrm{~m}$ of the formation, and the type locality at Sortehat seems to be the richest of the studied sections (Fig. 3).

Most of the analysed samples have hydrogen index (HI) values below 50 (Fig. 4). However, HI values between 100 and 500 are typically recorded in the lower part of the formation. The thickness of this zone of enrichment varies from more than $20 \mathrm{~m}$ in the Sortehat section to less than $5 \mathrm{~m}$ in the Goniomyakløft section with apparant intermediate values in most other sections (Fig. 3). Only a poor correlation between TOC and HI is recognised for samples with $\mathrm{HI}>100$ (Fig. 4).

\section{Sulphur}

The ratio between TOC and TS (total sulphur) has been suggested as a good indicator for distinguishing between marine and fresh water deposited organic-rich shales (Berner \& Raiswell, 1984). This method has been successfully applied in the interpretation of other units in East Greenland (Christiansen et al., 1990, 1992; Dam \& Christiansen, 1990).

Most of the analysed samples have low TS values (below $0.1 \%$ ) which point towards a fresh water or brackish depositional environment for most of the Sortehat Formation. Samples with TS $>0.2 \%$ and a positive correlation between TOC and TS have been recognised (Fig. 5). Especially in the Goniomyakløft section it is 
<smiles>I[I-]I</smiles> 


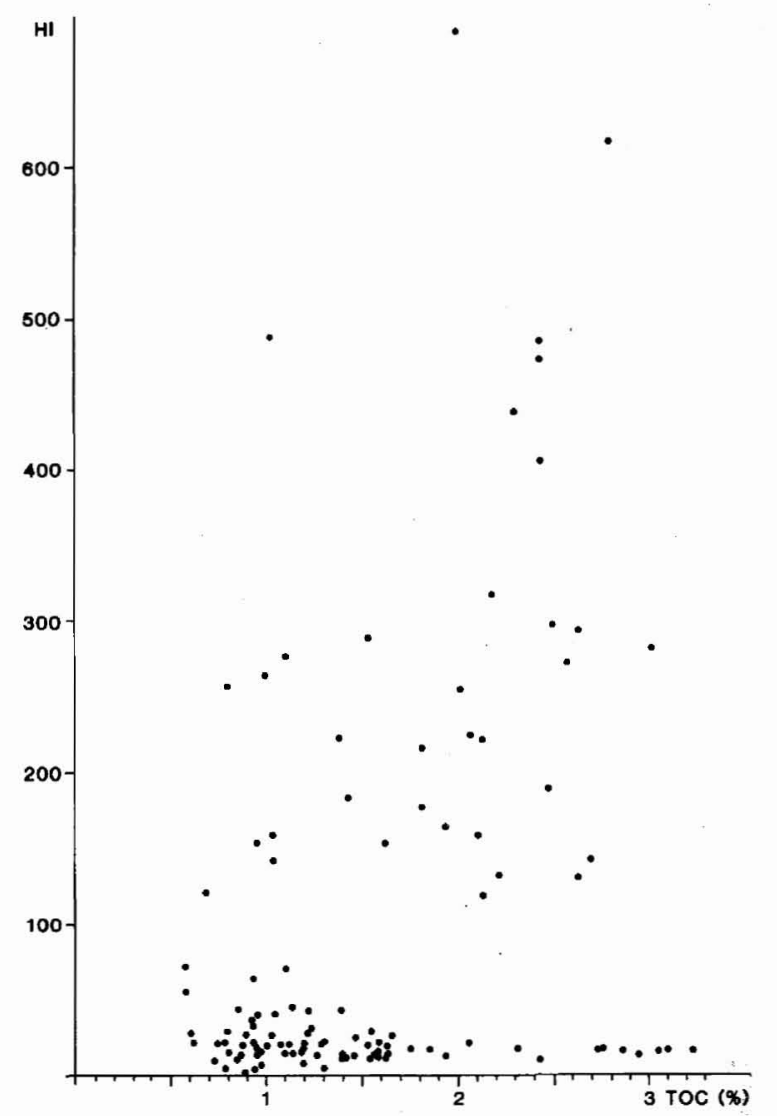

Fig. 4. Plot of TOC versus hydrogen index (HI) for all the analysed samples.

obvious that TS increases towards the top of the section (Fig. 3), coinciding with the interval where marine macrofossils have been found.

All of the samples with $\mathrm{HI}>50$ are from the low TS interval suggesting that any hydrocarbon source rock within the Sortehat Formation was deposited in a brackish or fresh water depositional environment.

\section{Palynofacies}

The content and composition of the organic matter (OM) vary significantly stratigraphically but appear much more constant geographically.

The visually identified composition of the organic content distinctly defines three palynofacies. Facies 1 has Botryococcus sp. (20-40\%) and spores and pollen (20$40 \%$ ) as the dominant organic constituents together with some very fine-grained amorphous kerogen (5-20\%) and subordinate woody and coaly material $(20 \%)$. Facies 2 is a spore and pollen (40-50\%) and brown to black woody material $(40-50 \%)$ dominated facies and facies 3 is completely dominated by large black or less frequently brown woody material $(60-90 \%)$ associated with spores and pollen $(10-40 \%)$.

The stratigraphic occurrence of these facies is cyclic, and the majority of sections is composed of facies 1, 2, 1, 2. Facies 3 is only recorded in the Sortehat and Pelion 2 sections, where it comprises approximately the upper half of the formation. The composite thickness of facies 1 (the potentially productive zone) varies from $2 \mathrm{~m}$ in Goniomyakløft to approximately $20 \mathrm{~m}$ in the Sortehat section.

The facies succession 1-2(-3) shows a coarseningupward trend with respect to the size of the woody fragments and reflects presumably a shallowing upwards trend. The abundant Botryococcus in the lower part and the very restricted marine microflora throughout the unit combined with locally more frequent acritarchs, Veryhachium sortehatense Fensome, 1979, and dinoflagellate cysts, Nannoceratopsis gracilis (Alberti) Evitt, 1962, strongly indicate an overall marginal marine, brackish water environment throughout the formation. The high content of Botryococcus in facies 1 may indicate a more freshwater influenced depositional environment compared to facies 2 and especially facies 3 which is brackish or marginal marine. The amorphous kerogen that characterises facies 1 indicates a rapid deposition of the organic matter under anoxic conditions in the bottom sediments.

\section{Biomarkers}

The 15 samples analysed for biomarkers are all from the potentially hydrocarbon productive part of the formation. They are from three different localities: nine samples are from the Sortehat section, covering the low-

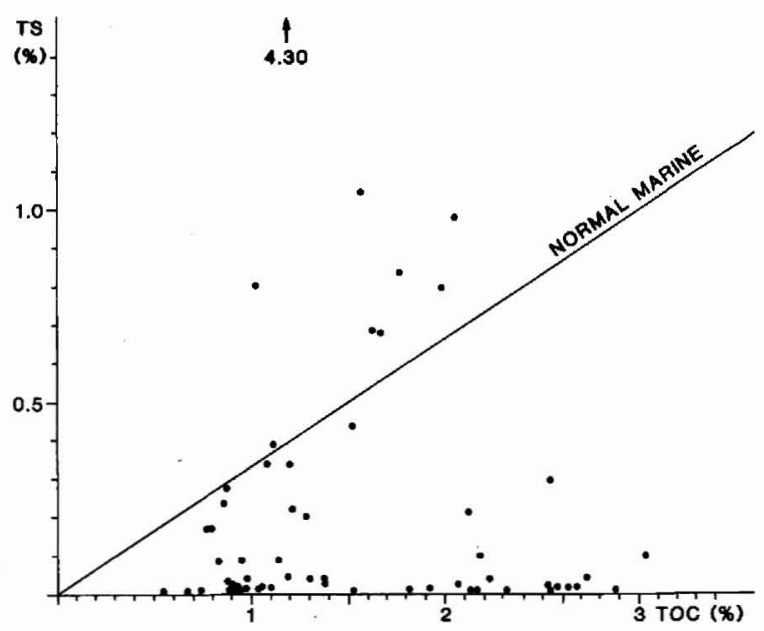

Fig. 5. Total sulphur (TS)-TOC plot. Points falling on the regression line are considered normal marine, points below are fresh to brackish water influenced, while points above belong to an anoxic-sulphidic depositional environment (adopted from Berner \& Raiswell, 1984). 
Table 1. Rock-Eval pyrolysis and total sulphur data

\begin{tabular}{lccccccccc}
\hline Sample & Section & m a.b. & S1 & S2 & $\begin{array}{c}\text { TOC } \\
\% \text { wt }\end{array}$ & HI & $\begin{array}{c}T_{\max } \\
{ }^{\circ} \mathrm{C}\end{array}$ & $\begin{array}{c}\text { TS } \\
\% \text { wt }\end{array}$ \\
\hline 195561 & SOR & 24 & 0.00 & 0.40 & 1.24 & 32 & 440 & - \\
195562 & - & 22 & 0.00 & 3.86 & 2.70 & 143 & 444 & - \\
195563 & - & 20 & 0.04 & 8.50 & 3.02 & 281 & 445 & 0.10 \\
195564 & - & 18 & 0.00 & 0.19 & 1.59 & 12 & 435 & - \\
195565 & - & 16 & 0.00 & 0.30 & 0.57 & 53 & 440 & - \\
195566 & - & 12 & 0.01 & 3.22 & 1.82 & 177 & 444 & - \\
195567 & - & 8 & 0.05 & 7.08 & 2.58 & 274 & 442 & 0.02 \\
195568 & - & 4 & 0.08 & 7.51 & 2.51 & 299 & 433 & - \\
195569 & - & 0 & 0.01 & 4.69 & 2.47 & 190 & 443 & 0.02 \\
327398 & GON & 7 & 0.00 & 0.18 & 0.78 & 23 & 436 & 0.17 \\
327397 & - & 5 & 0.00 & 0.54 & 1.14 & 47 & 440 & 0.09 \\
327396 & - & 3 & 0.01 & 3.42 & 2.64 & 130 & 444 & 0.04 \\
327395 & - & 2 & 0.05 & 3.21 & 1.91 & 168 & 440 & 0.02 \\
346678 & LIA & - & 0.00 & 1.90 & 0.74 & 257 & 444 & - \\
346677 & - & - & 0.03 & 13.57 & 1.98 & 685 & 443 & 0.80 \\
\hline
\end{tabular}

SOR: Sortehat section; GON: Goniomyakløft section; LIA: Liaselv section - see Fig. 1 for location of sections; m a.b.: metres above base of formation; S1: Mg hydrocarbons per gramme rock released upon thermovaporisation in Rock-Eval pyrolysis; S2: Mg hydrocarbons per gramme rock generated in Rock-Eval pyrolysis; TOC: total organic carbon content in per cent weight; HI: hydrogen index, S2/TOC; TS: total sulphur content in per cent weight.

ermost $20 \mathrm{~m}$ of the formation, four samples are from the Goniomyakløft section, covering the lowermost $5 \mathrm{~m}$ of the formation and two samples are from Liaselv. Screening by the Rock-Eval method gave TOC-values of $0.6-3 \%, \mathrm{~S}_{2}$ values of $0.4-8 \mathrm{mgHC} / \mathrm{g}$ rock, and hydrogen indices between 200 and 700 (Table 1). $T_{\max }$ values around $440^{\circ} \mathrm{C}$ indicate immature to early mature condi-

Table 2. Compound distribution in extractable organic matter

\begin{tabular}{lccccc}
\hline Sample & $\begin{array}{c}\text { EOM } \\
\text { mg/g rock }\end{array}$ & $\begin{array}{c}\text { EOM } \\
\text { mg/g TOC }\end{array}$ & $\begin{array}{c}\text { SAT }+ \\
\text { ARO } \%\end{array}$ & $\begin{array}{c}\text { NSO } \\
\%\end{array}$ & $\begin{array}{c}\text { ASPH } \\
\%\end{array}$ \\
\hline 195561 & 0.42 & 34 & 13 & 45 & 42 \\
195562 & 0.55 & 20 & 16 & 45 & 39 \\
195563 & 0.82 & 27 & 17 & 40 & 43 \\
195564 & 0.28 & 18 & 10 & 42 & 48 \\
195565 & 0.29 & 51 & 19 & 37 & 44 \\
195566 & 0.35 & 19 & 18 & 41 & 41 \\
195567 & 0.84 & 33 & 29 & 34 & 37 \\
195568 & 1.00 & 40 & 27 & 38 & 35 \\
195569 & 0.36 & 15 & 30 & 45 & 25 \\
327398 & 0.21 & 27 & 11 & 42 & 47 \\
327397 & 0.34 & 30 & 22 & 36 & 42 \\
327396 & 0.49 & 19 & 21 & 41 & 38 \\
327395 & 0.63 & 33 & 25 & 37 & 38 \\
346678 & 0.17 & 23 & 25 & 25 & 50 \\
346677 & 0.39 & 20 & 34 & 21 & 45 \\
\hline
\end{tabular}

EOM: Extractable Organic Matter; SAT: Saturates; ARO: Aromatics; NSO: Compounds containing nitrogen, sulphur or oxygen; ASPH: Asphaltenes. tions with respect to hydrocarbon generation for all the investigated samples (Table 1).

According to sulphur analyses and palynological observations the samples selected for biomarker analyses all derive from the brakish water part of the formation corresponding to palynofacies 1 (and 2).

\section{Gas chromatography}

Extract values are shown in Table 2 and average $0.48 \pm 0.06 \mathrm{mg} / \mathrm{g}$ rock or $27 \pm 2 \mathrm{mg} / \mathrm{g}$ TOC.

The overall envelope of the gas-chromatograms is similar for all samples, as seen by a constant front-end dominance of the $\mathrm{C}_{16}-\mathrm{C}_{21} n$-alkanes. This predominance terminates either abruptly with very low abundance of longer chain $n$-alkanes, e.g. GGU 195566 (Fig. 6) or by gradual decreasing amounts of longer chain $n$-alkanes, e.g. GGU 195567 (Fig. 6). A clear distinction into two groups can be made by counting the number of $n$-alkanes attaining more than half the intensity of the highest peak (Table 3). Nine samples fall into the first group, where four to six peaks protrude half the maximum intensity line. The six remaining samples have nine to 12 peaks reaching above that line (i.e. $\mathrm{C}_{15}-\mathrm{C}_{27} n$-alkanes).

The commonly used carbon preference index CPI-1 comprising the $n-\mathrm{C}_{24}$ to $n$ - $\mathrm{C}_{32}$ alkanes is of no real value here because of the front-end bias. Among the prevailing $n$-alkanes, however, a slight odd over even dominance is observed.

Isoprenoids and a few abundant aromatic compounds 
195566

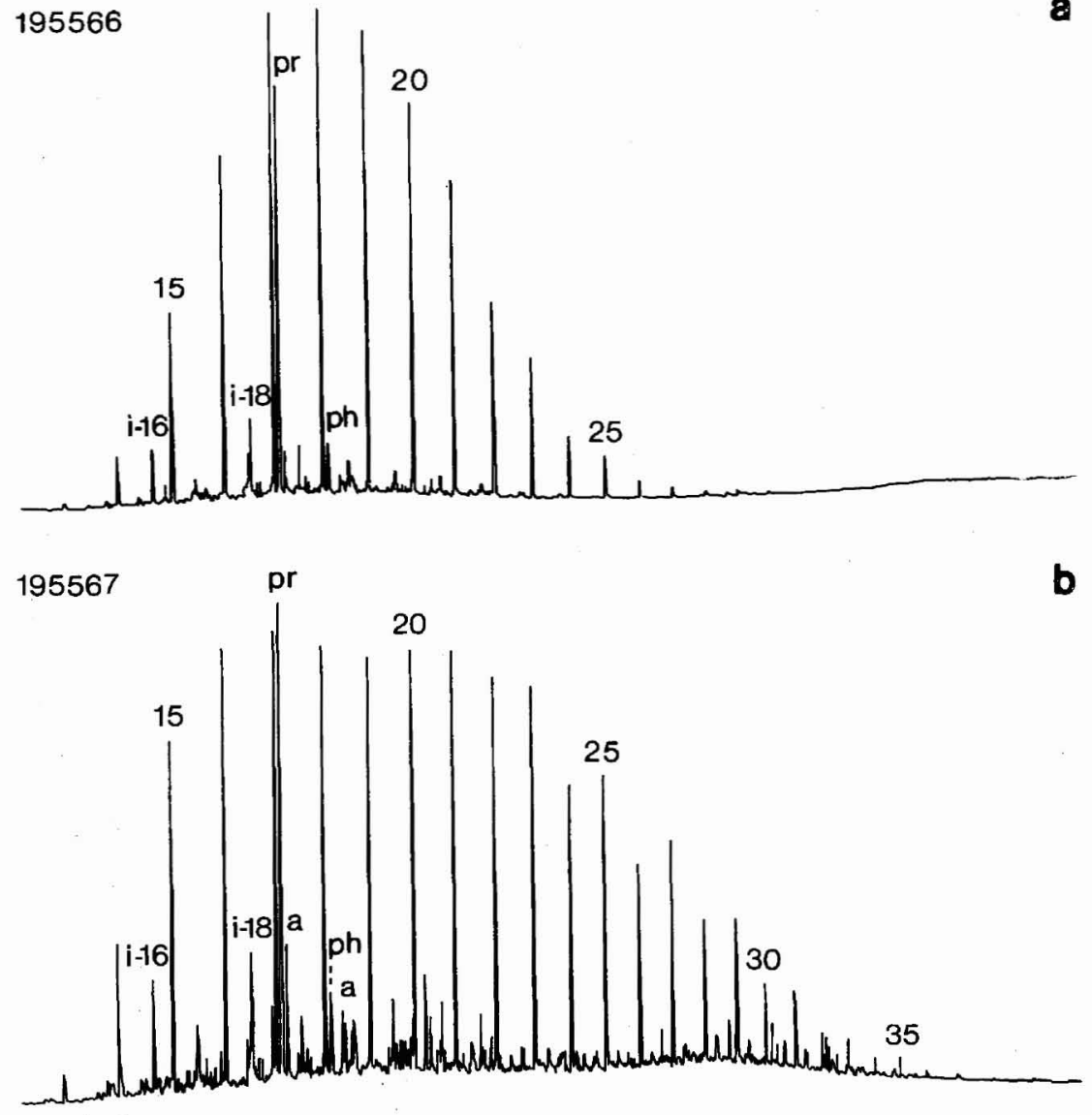

Fig. 6 a, b. Gas chromatograms showing the two $n$-alkane distribution types observed in the investigated samples. Notice the difference in $n$-alkane range. ' $i$ ' denotes regular isoprenoids, ' $a$ ' denotes identifiable aromatics. (phenanthrene and the methyl-phenanthrenes) can be identified among the $n$-alkanes. Pristane and phytane are present in significant amounts, pristane in a few cases exceeding the $n-\mathrm{C}_{17}$ peak. Pristane $/ n-\mathrm{C}_{17}$ ratios average $0.85 \pm 0.06$. Pristane/phytane ratios also are very high, ranging between 4 and 10 (Table 3). The samples with the highest pristane $/ n-\mathrm{C}_{17}$ values as well as highest pristane/ phytane values, are those with the best potential for hydrocarbon generation (cf. Table 1 and 3 ).

Phytane $/ n-\mathrm{C}_{18}$ ratios average $0.19 \pm 0.01$. Variations in $n-\mathrm{C}_{17} / n-\mathrm{C}_{27}$ ratios seem to reflect the earlier mentioned grouping on the basis of $n$-alkane range, and bear no relation to maturity.

Phenanthrene and the methylphenanthrenes are easily identified on the chromatograms (denoted ' $a$ ' in Fig. 6). A tentative methylphenanthrene index MPI-1 (Radke, 1988) calculated from seven of the samples gave an average value of $0.57 \pm 0.01$ (Table 3 ), usually indicating presence within the oil window. This index is thus somewhat high compared to other maturity indicators (see next section).
Gas chromatography - mass spectrometry (GCMS)

In the following, data on tri- and pentacyclic terpanes, steranes, isoprenoids, aromatic steranes and methylsteranes are presented.

Molecular maturity indicators. Calculated molecular maturity parameters encompass the following ratios and values: moretane/hopane: $0.31 \pm 0.01 ; \% \mathrm{C}_{29} 20 \mathrm{~S}$ steranes: $36 \pm 2$; $\% \mathrm{C}_{31}-22 \mathrm{~S}$ hopanes: $60 \pm 2$ and $\% \mathrm{C}_{20}$ triaromatic steranes: $28 \pm 3$ (Table 4). Except for the isomerisation of hydrogen at $\mathrm{C}_{14}$ and $\mathrm{C}_{17}$ in the $\mathrm{C}_{29}$ steranes $(\% \alpha \beta \beta)$, values are remarkably consistent. The hopanes have attained the equilibrium value approximately $60 \% \mathrm{C} 22 \mathrm{~S}$. A few vitrinite reflectance measurements from Lepidopteriselv and Liaselv sections gave a rank of $0.55 \% R_{0}$ which is in accordance with Rock-Eval data and the molecular parameters presented above. The formation is thus immature to early mature with respect to hydrocarbon generation. This consistency in maturity rank for the 
Table 3. GC parameters from combined saturate and aromate fraction

\begin{tabular}{lccrrrr}
\hline Sample & $\mathrm{pr} / n \mathrm{C}_{17}$ & $\mathrm{ph} / n \mathrm{C}_{18}$ & $\mathrm{pr} / \mathrm{ph}$ & $n \mathrm{C}_{17} / n \mathrm{C}_{27}$ & $\mathrm{mpi}-1$ & n. $n$-alk \\
\hline 195561 & 0.65 & 0.22 & 3.80 & 3.04 & 0.52 & 10 \\
195562 & 0.83 & 0.18 & 5.06 & 2.87 & 0.56 & 9 \\
195563 & 1.40 & 0.25 & 10.20 & 6.44 & - & 4 \\
195564 & 0.79 & 0.27 & 3.52 & 6.99 & 0.61 & 5 \\
195565 & 0.63 & 0.19 & 4.13 & 16.33 & - & 6 \\
195566 & 0.85 & 0.15 & 7.76 & 29.08 & - & 5 \\
195567 & 1.05 & 0.25 & 5.39 & 2.31 & - & 12 \\
195568 & 0.97 & 0.20 & 6.22 & 3.22 & 0.60 & 10 \\
195569 & 1.02 & 0.21 & 5.48 & 2.67 & - & 9 \\
327398 & 0.66 & 0.20 & 4.37 & 6.81 & 0.62 & 6 \\
327397 & 0.59 & 0.14 & 4.86 & 1.41 & 0.57 & 11 \\
327396 & 0.65 & 0.12 & 7.38 & 29.63 & 0.54 & 5 \\
327395 & 0.54 & 0.14 & 4.93 & 3.37 & - & 6 \\
346678 & 0.82 & 0.15 & 8.53 & 68.67 & - & 4 \\
346677 & 1.26 & 0.18 & 10.12 & 23.02 & - & 4 \\
\hline
\end{tabular}

$\mathrm{pr} / n \mathrm{C}_{17}:$ ratio of pristane to $\mathrm{C}_{17} n$-alkane; $\mathrm{ph} / n \mathrm{C}_{18}$ : ratio of phytane to $\mathrm{C}_{18} n$-alkane; mpi-1: methylphenanthrene index-1; $1.5 \times(2-\mathrm{mp}+$ $3-\mathrm{mp}) /(\mathrm{p}+1-\mathrm{mp}+9-\mathrm{mp}) ; \mathrm{n} \cdot n$-alk: number of $n$-alkanes attaining more than half the peak height of the maximum peak in the combined saturate and aromatic gas chromatogram.

samples investigated allows most of the molecular parameters to be interpreted with respect to source variations.

Hopanes. Hopane to sterane ratios are high, averaging $28 \pm 4$ (Table 4). The hopane fingerprinting is in some ways quite remarkable with almost equal occurrences of $\mathrm{C}_{29}$-norhopane, $\mathrm{C}_{27} 17 \alpha$-trisnorhopane $(\mathrm{Tm})$ and $\mathrm{C}_{30}$-hopane (Fig. 7). Also the $\mathrm{C}_{31}$-homohopane is very abundant.
Extended hopanes beyond $\mathrm{C}_{31}$ are seen in low amounts. The $18 \alpha(\mathrm{H})$-trisnorhopane (Ts) and the 28,30-bisnorhopane are both present in trace amounts or absent.

Tricyclics terpanes. The most abundant tricyclic compound is a $\mathrm{C}_{20}$ species. The $\mathrm{C}_{23}$ tricyclic compound is only present in very small amounts. These are barely discernible on Fig. 7, but clearly picked on the SMIM fragmentograms (not shown). In the Sortehat section the ratio of $\mathrm{C}_{23}$ tricyclic/17 $\alpha$-hopane is 0.17 in the lowermost sample GGU 195569, decreasing upwards to 0.01 (Table 4). Other longer-chain tricyclic terpanes are absent.

Steranes. The low relative amounts of steranes consist of $\mathrm{C}_{27}$ and $\mathrm{C}_{29}$ isomers with a small but constant amount of $\mathrm{C}_{28}$ isomers of $12 \%$ (Fig. 8). The ratio of $\mathrm{C}_{27}$ to $\mathrm{C}_{29}$ steranes is on average $0.54 \pm 0.05$ - a clear dominance of the $\mathrm{C}_{29}$ steranes (Table 5). $\mathrm{C}_{30}$ steranes are absent, except for the lowermost sample in the Sortehat section (GGU 195569) in which traces are observed. Diasteranes are almost equally abundant as the regular steranes. An example of the sterane mass fragmentogram $(\mathrm{m} / \mathrm{z}, 217)$ is shown in Fig. 7.

4-methyl steranes are present in slightly lower amounts than the regular steranes. $\mathrm{C}_{28}$ isomers are most abundant, followed by $\mathrm{C}_{29}$ and $\mathrm{C}_{30}$ isomers. No identification of the different isomers have been attempted.

The content of low molecular weight (LMW) steranes, $\mathrm{C}_{21}, \mathrm{C}_{22}$ and $\mathrm{C}_{23}$ relative to the total sterane content is fairly constant. $\mathrm{C}_{21}$ steranes are most abundant (Fig. 8), $\mathrm{C}_{23}$ isomers least abundant.

Table 4. Parameters from GC-MS analysis

\begin{tabular}{lcccccccc}
\hline Sample & $\% \mathrm{C}_{31}-22 \mathrm{~S}$ & $\% \mathrm{C}_{29}-20 \mathrm{~S}$ & $\% \mathrm{C}_{29}$-abb & $\mathrm{Ts} / \mathrm{Tm}$ & $\mathrm{MOR} / \mathrm{HOP}$ & $\mathrm{TC} / 17 \alpha$ & HOP/ST & $\% \mathrm{C}_{20} \mathrm{TA}$ \\
\hline 195561 & 58 & 28 & 1 & 0.01 & 0.38 & 0.00 & 20 & n.d. \\
195562 & 61 & 32 & 17 & 0.01 & 0.26 & 0.01 & 33 & n.d. \\
195563 & 57 & 35 & 18 & 0.03 & 0.37 & 0.02 & 10 & 0.32 \\
195564 & 60 & n.d. & n.d. & 0.00 & 0.32 & 0.01 & 21 & 0.48 \\
195565 & 62 & 47 & 23 & 0.00 & 0.25 & 0.01 & 35 & 0.38 \\
195566 & 59 & 34 & 15 & 0.01 & 0.34 & 0.00 & 32 & n.d. \\
195567 & 57 & 36 & 23 & 0.10 & 0.31 & 0.03 & 10 & 0.23 \\
195568 & 57 & 36 & 10 & 0.07 & 0.38 & 0.02 & 10 & 0.17 \\
195569 & 59 & 39 & 32 & 0.16 & 0.29 & 0.17 & 7 & 0.21 \\
327398 & 62 & 33 & 19 & 0.01 & 0.27 & 0.00 & 28 & 0.29 \\
327397 & 62 & n.d. & n.d. & 0.01 & 0.34 & 0.00 & 39 & 0.27 \\
327396 & 61 & 37 & 18 & 0.01 & 0.33 & 0.00 & 72 & 0.21 \\
327395 & 60 & 28 & 16 & 0.03 & 0.23 & 0.00 & 16 & 0.10 \\
346678 & 64 & n.d. & n.d. & 0.01 & 0.24 & 0.00 & 36 & 0.43 \\
346677 & 59 & 44 & 12 & 0.01 & 0.30 & 0.00 & 50 & 0.24 \\
\hline
\end{tabular}

Ts: $18 \alpha(\mathrm{H})$-22,29,30-trisnorneohopane; Tm: $17 \alpha(\mathrm{H})-22,29,30$-trisnorhopane; MOR: $\mathrm{C}_{30}$-moretane; HOP: $\mathrm{C}_{30}$-hopane; TC/17 $\alpha$ : ratio of $\mathrm{C}_{23}$ tricyclic to $17 \alpha(\mathrm{H})$-hopane; ST: $\mathrm{C}_{29}$-sterane; $\% \mathrm{C}_{20} \mathrm{TA}: \mathrm{C}_{20} /\left(20+\mathrm{C}_{28}\right)$ triaromatics; n.d.: not detected due to very low amounts. 
14

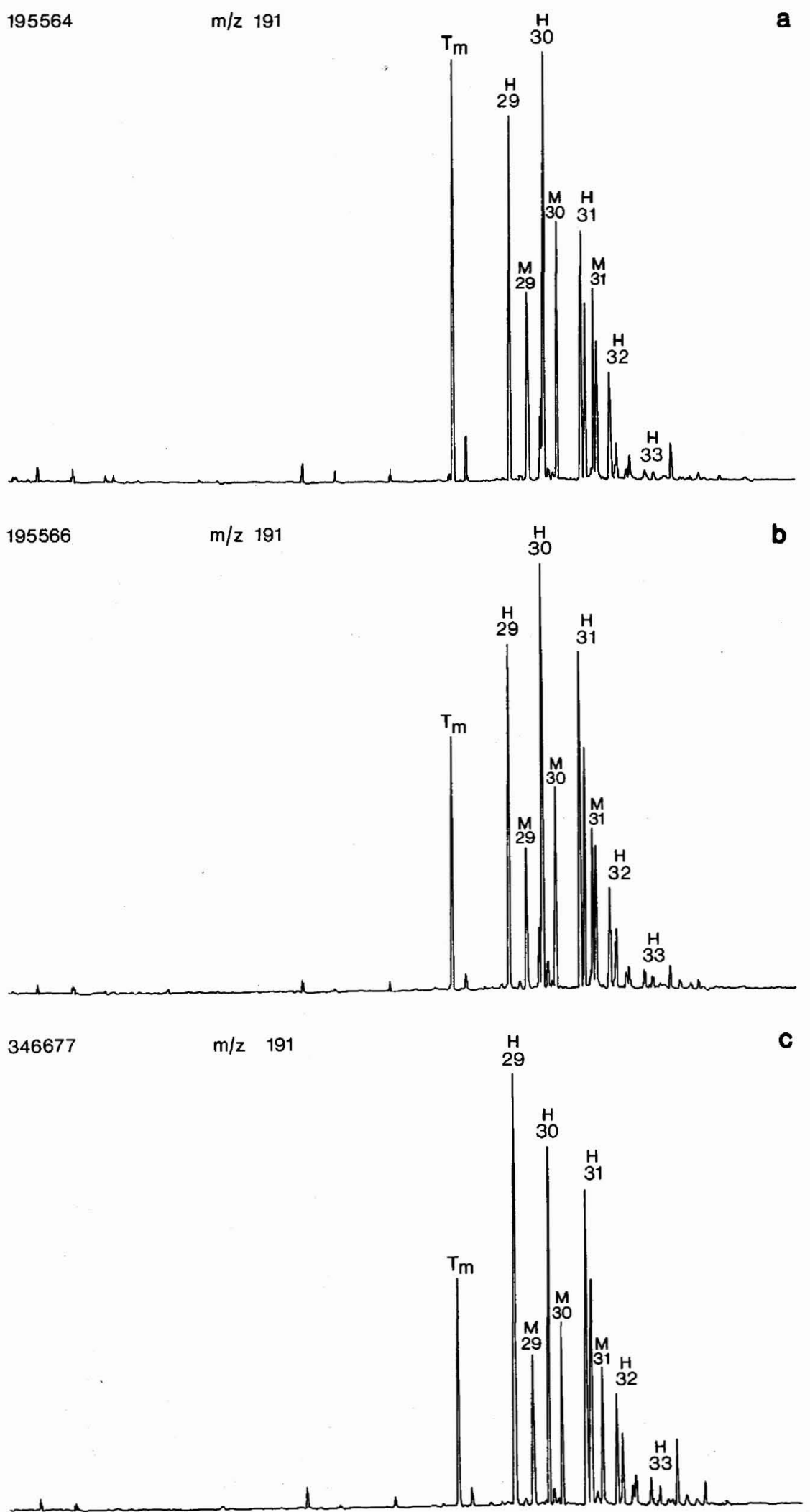

fragmentograms $(\mathrm{m} / \mathrm{z}$ 191) showing the distribution of pentacyclic terpanes. Peaks are identified in Table 6. 
Fig. 8. Mass fragmentogram $(\mathrm{m} / \mathrm{z}$. 217) showing the distribution of steranes. Numbers refer to number of carbon atoms. Identification of peaks in Table 6 .

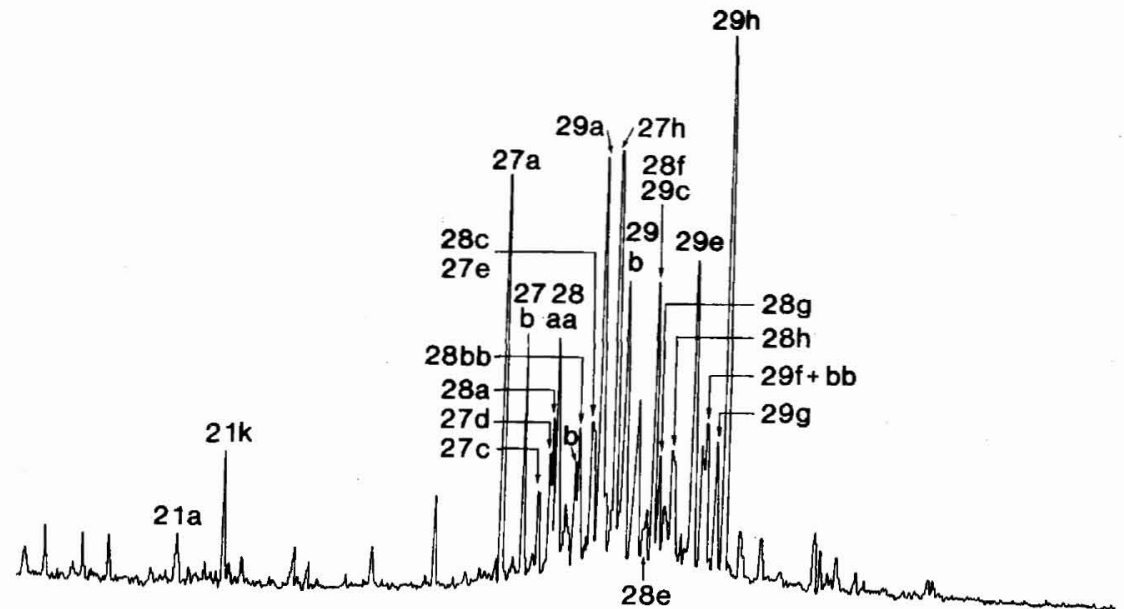

\section{Discussion}

The uniform and general low maturity rank of the samples from the lower part of the Sortehat Formation allow a discussion of the geochemistry without the influence of maturity effects. Except for the variance in $n$-alkane distribution among the samples, and the probable marine influence on sample GGU 195569 (presence of $\mathrm{C}_{30}$ steranes and $\mathrm{Ts}$ and high tricyclic/17 $\alpha$-hopane ratio), the biomarker distribution is uniform and suggests a common interpretation for the biological sources, depositional environment, and diagenetic conditions.

The dominant range of low molecular weight $n$-alkanes points towards bacteria and algae as the major contributors of organic material. This is in accordance with the presence of Botryococcus and amorphorus orga-

Table 5. Sterane percentages

\begin{tabular}{lcccc}
\hline Sample & $\% \mathrm{C}_{27}$ & $\% \mathrm{C}_{28}$ & $\% \mathrm{C}_{29}$ & $\mathrm{C}_{27} / \mathrm{C}_{29}$ \\
\hline 195561 & 24 & 8 & 68 & 0.35 \\
195562 & 38 & 8 & 54 & 0.70 \\
195563 & 27 & 13 & 60 & 0.45 \\
195564 & 35 & 13 & 52 & 0.67 \\
195565 & 33 & 0 & 67 & 0.49 \\
195566 & 19 & 9 & 72 & 0.26 \\
195567 & 28 & 13 & 59 & 0.47 \\
195568 & 28 & 13 & 59 & 0.47 \\
195569 & 39 & 14 & 48 & 0.81 \\
327398 & 18 & 15 & 68 & 0.26 \\
327397 & 43 & 9 & 48 & 0.90 \\
327396 & 39 & 9 & 52 & 0.75 \\
327395 & 24 & 9 & 67 & 0.36 \\
346678 & 27 & 33 & 40 & 0.68 \\
346677 & 25 & 24 & 51 & 0.49 \\
\hline
\end{tabular}

Based on $\alpha \alpha \alpha 20 \mathrm{R}$ isomer peak heights. nic matter. Samples containing a significant amount of long chain $n$-alkanes have probably received additional organic input from land run-off, i.e. higher land plants with a vascular system (Volkman, 1988). Hence the $n$-alkane parameter in Table 3 is believed to reflect fluctuations in land plant input relative to autochthonous organic matter.

Pristane/phytane values as high as these reported here have traditionally been ascribed to coaly material (Chaffe et al., 1986). A more plausible explanation in this marginal marine, brackish water setting is partly oxic conditions relating high pristane contents directly to primary organic matter production (i.e. chlorophyll, Didyk et al., 1978; ten Haven et al., 1987) from algae and land plants. This also explains the covariance of pristane/phytane ratios and hydrocarbon potential $\left(\mathrm{S}_{2}\right)$ from Rock-Eval pyrolysis. Bacteria synthesise either pristane (Hunt,' 1979) or phytane precursors, the latter often associated with halophilic bacteria, the growth of which is not promoted in a low saline environment as discussed here (ten Haven et al., 1987).

Besides pristane and phytane, the presence of $\mathrm{i}_{-} \mathrm{C}_{16}$ and i- $\mathrm{C}_{18}$ acyclic isoprenoids also concurs with marine sources (Murchison, 1987 and references therein), where longer chain isoprenoids are almost absent. Squalane occurs in only limited amounts in a few samples, and botryococcane was not detected, despite the presence of Botryococcus algal remains from visual inspection. This is not necessarily contradictory as not all Botryococcus types synthesise botryococcenes. Furthermore, fossilisation of botryococcenes is not always favoured by the diagenetic conditions (Derenne et al., 1988).

The hopane fingerprinting is characterised by a dominance of $\mathrm{Tm}, \mathrm{C}_{29}$ norhopane, $\mathrm{C}_{30}$ hopane and $\mathrm{C}_{31}$ homohopane. Extended hopanes are very low in abundance and 
Table 6. Peak identifications

\begin{tabular}{ll}
\hline Terpanes \\
Tm $\quad 17 \alpha(\mathrm{H})-22,29,30$-trisnorhopane \\
H $\quad 17 \alpha(\mathrm{H}), 21 \beta(\mathrm{H})$-hopanes, respective carbon number \\
M $\quad 17 \beta(\mathrm{H}), 21 \alpha(\mathrm{H})$-moretanes, respective carbon number \\
Steranes \\
a $\quad 13 \beta(\mathrm{H}), 17 \alpha(\mathrm{H})$-diasterane 20S \\
b & $13 \beta(\mathrm{H}), 17 \alpha(\mathrm{H})$-diasterane 20R \\
c & $13 \alpha(\mathrm{H}), 17 \beta(\mathrm{H})$-diasterane 20S \\
d & $13 \alpha(\mathrm{H}), 17 \beta(\mathrm{H})$-diasterane 20R \\
e & $5 \alpha(\mathrm{H}), 14 \alpha(\mathrm{H}), 17 \alpha(\mathrm{H})$-sterane $20 \mathrm{~S}$ \\
f & $5 \alpha(\mathrm{H}), 14 \beta(\mathrm{H}), 17 \beta(\mathrm{H})$-sterane 20R \\
g & $5 \alpha(\mathrm{H}), 14 \beta(\mathrm{H}), 17 \beta(\mathrm{H})$-sterane 20S \\
h & $5 \alpha(\mathrm{H}), 14 \alpha(\mathrm{H}), 17 \alpha(\mathrm{H})$-sterane 20R \\
\hline
\end{tabular}

sulphur is absent. The high $\mathrm{C}_{29}$ norhopane content cannot be ascribed to either carbonate or evaporite facies (Waples \& Machihara, 1990), but fits better with parts of the geochemistry of fresh to brackish water, nonmarine oils from China (Pu \& Baisheng, 1987), where $\mathrm{C}_{29}$ norhopane is the second highest peak among the hopanes in some oils. Derenne et al. (1988), investigating torbanites, found several of the same characteristics as found in the Sortehat material, namely high $\mathrm{C}_{29} / \mathrm{C}_{30}$ hopane ratio, high hopane/sterane ratio and high pristane/phytane values (though overall low concentrations of both isoprenoids). This means that even though the biological source in torbanites is known to be algae, the biomarkers have a marked microbial/bacterial distribution. Whether the principal biological source in the Sortehat Formation has been algae or bacteria is therefore also difficult to determine. Also, rather than viewing the Sortehat Formation hopane distribution as displaying unusually high $\mathrm{Tm}, \mathrm{C}_{29}$, $\mathrm{C}_{30}$ and $\mathrm{C}_{31}$ contents, the same pattern emerges from primary absence of the extended hopanes and Ts, both of which are in accordance with a low salinity, clastic depositional environment.

The relatively low $\mathrm{C}_{27}-\mathrm{C}_{29}$ sterane content can originate from eucaryotic organisms, vascular plants and, more rarely, cyanobacteria (Volkman, 1988). In view of the clastic depositional environment of the Sortehat Formation and the visually observed plant remains, land plants must have contributed significantly to the $\mathrm{C}_{29}$ sterane dominance. However, long chain $n$-alkanes together with $\mathrm{C}_{29}$ steranes can also be derived from some algal species (Volkman, 1988 and references therein). The $C_{27}$ steranes are considered of marine algal origin.

The origin of the $\mathrm{C}_{28}-\mathrm{C}_{30}$ suite of 4-methyl steranes (not to be confused with $\mathrm{C}_{30}$ dinosteranes) is unknown, but they are found in both marine and freshwater material (Waples \& Machihara, 1990).

Bearing in mind the low maturity of the samples, the diasterane content is quite significant. Diasteranes have no immediate biological precursors, but are thought to be rearranged from normal steranes. The rearrangement mechanism is not well resolved, but it is observed that diasteranes occur more frequently in clastic sediments than in, for example, carbonates (Waples \& Machihara, 1990).

The majority of biomarkers are common for all the investigated samples. This means that the palynofacies assemblages 1 and 2 cannot be discerned on the basis of biomarkers. The exceptions are the hydrogen index and pristane/phytane values which show some covariance, e.g. higher values in facies 1 than in facies 2 .

Many of the characteristics seen in the Sortehat Formation are shared with the Group VII marine anoxic siliciclastic source rocks and oils of Mello et al. (1988a,b). Features in common are pristane/phytane, $n$-alkane envelope and hopane fingerprinting. The relative content of tricyclic terpanes are lower in the Sortehat Formation, but this may be caused by differences in maturity level, as the tricyclics are more thermally stable than the pentacyclics. The steranes differ, primarily as a result of reversed $\mathrm{C}_{27} / \mathrm{C}_{29}$ ratio dominance, pointing to a stronger, true marine saline influence in Group VII of Mello et al. (1988a,b). The lower Toarcian shales of SW Germany and the Parish Basin are cited as also belonging to this group.

Sulphur/TOC data for the lower Toarcian shales in northern Italy tabulated in Farrimond et al. (1989) are very similar to the Sortehat Formation values, suggesting brackish water conditions in the Tethys area. Another common feature between the Sortehat Formation material and the northern Italy material is the low sterane content, possibly brought about by degradation in the upper water masses, whereas the abundant hopanes are produced from bacterial activity in settled organic matter, where anoxicity prevails.

In summary, the organic geochemistry indicates that the lower part of the Sortehat Formation was deposited in brackish-marine waters low in oxygen. This is supported by the restricted floras of palynologial facies 1 and 2 . Bacteria, algae and land plants have all been major contributors to the pool of organic matter. The organic-rich brackish water deposits pass upwards into organic-poor normal marine shales.

\section{Conclusions}

Evaluation of the Lower Jurassic Sortehat Formation shales has led to the following conclusions:

1) Salinities in the depositional environment increase from bottom to top. Low saline brackish water condi- 
tions are succeeded by marginal marine conditions as evidenced by sulphur content and palynology.

2) Potential for generation of hydrocarbons is limited and confined to the lowermost brackish water part of the formation.

3) Biomarker analyses of the potential source rocks substantiate a brackish water interpretation by showing high hopane/sterane ratios, $\mathrm{C}_{29}-\mathrm{C}_{31}$ hopane dominance, and high relative content of $\mathrm{Tm}$.

4) Other biomarker characteristics are the prevalence of $\mathrm{C}_{16}-\mathrm{C}_{21} n$-alkanes, the high pristane/phytane ratios, the low amounts of tricyclic terpanes, and the dominance of $n$ - $\mathrm{C}_{29}$ steranes.

5) A general sea level rise and increased circulation of marine water masses onto the shelf of central East Greenland during the Toarcian is responsible for the development seen in the Sortehat Formation.

\section{References}

Berner, R. A. \& Raiswell, R. 1984: C/S method for distinguishing freshwater from marine sedimentary rocks. Geology $\mathbf{1 2}$, $365-368$.

Bojesen-Kofoed, J. 1989: Organisk-geokemisk screeninganalyser, metoder og resultater. Analysemetoder ved DGU's source rock laboratorium. Danmarks geol. Unders. Intern rapport 5, $39 \mathrm{pp}$.

Chaffe, A. L., Hoover, D. S., Johns, R. B. \& Schweighardt, F. K. 1986: Biological markers extractable from coals. In Johns, R. B. (ed.) Biological markers in the sedimentary record, 311-345. Elsevier.

Christiansen, F. G., Boserup, J., Buchardt, B., Guvad, C., Hansen, K., Koch, C. J. W., Jensenius, J., Nielsen, G. S., NøhrHansen, H., Stouge, S., Thomsen, E. \& Østfeldt, P. 1989: Analytical programme and applied methods. In Christiansen, F. G. (ed.) Petroleum geology of North Greenland. Bull. Grønlands geol. Unders. 158, 21-26.

Christiansen, F. G., Olsen, H., Piasecki, S. \& Stemmerik, L. 1990: Organic geochemistry of Upper Palaeozoic lacustrine shales in the East Greenland basin. Org. Geochem. 16, 287 294.

Christiansen, F. G., Dam, G., Piasecki, S. \& Stemmerik, L. 1992: A review of Upper Palaeozoic and Mesozoic source rocks from onshore East Greenland. In Spencer, A. M. (ed.) Generation, accumulation and production of Europe's hydrocarbons. Proc. Eur. Ass. Petrol. Geology 2, 151-161.

Dam, G. 1991: Depositional evolution of a Lower Jurassic embayment succession, Neill Klinter Formation, Jameson Land Basin, East Greenland. Part 4 of an unpublished Ph.D. thesis, University of Copenhagen, $58 \mathrm{pp}$.

Dam, G. \& Christiansen, F. G. 1990: Organic geochemistry and source potential of the lacustrine shales of the Upper Triassic - Lower Jurassic Kap Stewart Formation, East Greenland. Mar. Petrol. Geol. 7, 428-443.

Derenne, S., Largeau, C., Casadevall, E. \& Connan, J. 1988: Comparison of torbanites of various origins and evolutionary stages. Bacterial contribution to their formation. Cause of the lack of botryococcane in bitumens. Org. Geochem. 12, 43-59.

Didyk, B. M., Simoneit, B. R. T., Brassell, S. C. \& Eglinton, G. 1978: Organic geochemical indicators of palaeoenvironmental conditions of sedimentation. Nature 272, 216-222.

Doyle, P. 1991: Belemnites from the Lower Jurassic of East Greenland and their biostratigraphical and biogeographical significance. Bull. geol. Soc. Denmark 39, 123-141.

Farrimond, P., Eglinton, G., Brassell, S. C. \& Jenkyns, H. C. 1989: Toarcian anoxic event in Europe: an organic geochemical study. Mar. Petrol. Geol. 6, 136-147.

ten Haven, H. L., de Leeuw, J. W., Rullkotter, J. \& Sinninghe Damste, J. S. 1987: Restricted utility of the pristane/phytane ratio as palaeoenvironmental indicator. Nature 330, 641-643.

Hunt, J. M. 1979: Petroleum geochemistry and geology, 617 pp. San Francisco: W. H. Freeman and Company.

Mello, M. R., Gaglianone, P. C., Brassell, S. C. \& Maxwell, J. R. 1988a: Geochemical and biological marker assessment of depositional environments using Brazilian offshore oils. Mar. Petrol. Geol. 5, 205-223.

Mello. M. R., Telnaes, N., Gaglianone, P. C., Chicarelli, M. I., Brassell, S. C. \& Maxwell, J. R. 1988b: Organic geochemical characterisation of depositional palaeoenvironments of source rocks and oils in Brazilian marginal basins. Org. Geochem. 13, (1-3), 31-45.

Murchison, D. G. 1987: Recent advances in organic petrology and organic geochemistry: an overview with some reference to 'oil from coal'. In Scott, A. C. (ed.) Coal, and coal-bearing strata. Spec. Publ. geol. Soc. Lond. 32, 257-302.

Piasecki, S. 1987: Leco/Rock-Eval screening analysis of the Upper Palaeozoic - Mesozoic sediments of Jameson Land, central East Greenland. Unpubl. intern. GGU rep., Part I: 61 pp., Part II: 68 pp.

Pu, F. \& Baisheng, Z. 1988: Biomarker characteristics of nonmarine oils in China. Org. Geochem. 13 (4-6), 627-632.

Radke, M. 1988: Application of aromatic compounds as maturity indicators in source rocks and crude oils. Mar. Petrol. Geol. 5, 224-236.

Steen, A. 1986: Gas chromatographic/mass spectrometric (GC/ MS) analysis of $\mathrm{C}_{27-30}$-steranes. Advances in organic geochemistry 1985. Org. Geochem. 10, 1137-1142.

Surlyk, F. 1977a: Mesozoic faulting in East Greenland. In Frost, R. T. C. \& Dikkers, A. J. (ed.) Fault tectonics in NW Europe. Geol. Mijnb. 56, 311-327.

Surlyk, F. 1977b: Stratigraphy, tectonics and palaeogeography of the Jurassic sediments of the areas north of Kong Oscars Fjord, East Greenland. Bull. Grønlands geol. Unders. 123, 56 pp.

Surlyk, F. 1990a: A Jurassic sea-level curve for East Greenland. Palaeogeogr., Palaeoclimat., Palaeoecol. 78, 71-85.

Surlyk, F. 1990b: Timing, style and sedimentary evolution of Late Palaeozoic - Mesozoic extensional basins of East Greenland. In Hardman, R. F. P. \& Brooks, J. (ed.) Tectonic events responsible for Britain's oil and gas reserves. Spec. Publ. geol. Soc. Lond. 55, 107-125.

Surlyk, F. 1991: Sequence stratigraphy of the Jurassic - lowermost Cretaceous of East Greenland. Bull. Am. Ass Petrol. Geol. 75(9), 1468-1488. 
Surlyk, F., Callomon, J. H., Bromley, R. G. \& Birkelund, T. 1973: Stratigraphy of the Jurassic - Lower Cretaceous sediments of Jameson Land and Scoresby Land, East Greenland. Bull. Grønlands geol. Unders. 105, $76 \mathrm{pp}$.

Surlyk, F., Clemmensen, L. B. \& Larsen, H. C. 1981: PostPalaeozoic evolution of the East Greenland continental margin. In Kerr, J. W. \& Ferguson, A. J. (ed.) Geology of the North Atlantic borderlands. Mem. Can. Soc. Petrol. Geol. 7 , 611-645.
Volkman, J. K. 1988: Biological marker compound as indicators of the depositional environments of petroleum source rocks. In Fleet, A. J., Kelts, K. \& Talbot, M. R. (ed.) Lacustrine petroleum source rocks. Spec. Publ. geol. Soc. Lond. 40, 103-122.

Waples, D. W. \& Machihara, T 1990: Application of sterane and triterpane biomarkers in petroleum exploration. Bull. Can. Petrol. Geol. 38(3), 357-380. 